\title{
Decreasing of the company indebtedness through financial investment
}

\author{
Katarína Čulková ${ }^{1,2, *}$, Marcela Taušová ${ }^{1,2}$ \\ ${ }^{1}$ Department of Business and Management, Facutly BERG, Košice, Slovakia \\ ${ }^{2}$ Technical University Košice, TU Košice, Slovakia
}

\section{Email address:}

katarina.culkova@tuke.sk (K. Čulková), marcela.tausova@tuke.sk (M. Taušová)

\section{To cite this article:}

Katarina Culkova, Marcela Tausova. Decreasing of the Company Indebtedness Through Financial Investment. Journal of Investment and Management. Vol. 2, No. 2, 2013, pp. 23-27. doi: 10.11648/j.jim.20130202.11

\begin{abstract}
Present period of business brings problems, when many companies achieve profit by the way of indebtedness against external environment, in which company exists. Mainly due to the external relations company has almost regular problems with indebtedness and consequent paying disability. Goal of the paper is to show impact of financial investment to the indebtedness decreasing by the way of securities portfolio. Research database of securities value is used from the results of periodic auctions, according which there is calculated revenue of investment and investment risk, as it is defined by Brealey et. al (2000). Decision to solve the situation through financial investment can help financial managers to make effective solving of the indebtedness that can greatly determine further orientation of the company in the future.
\end{abstract}

Keywords: Indebtedness; Liquidity; Financial investment; Portfolio of securities; Risk

\section{Introduction}

Main goals of any organization that wants to be successful at the market are achieving of high profit and sales and obtaining of competition advantage. But we must speak also about influencing of the profit achievement by financial situation of the organization, mainly in area of indebtedness and paying ability. Proper management of indebtedness and paying ability of the organization contributes to decreasing of risk that is connected with indebtedness and paying disability, and it should belong among main goals of the organization managers during managing of financial processes in the condition of market economy. Knowing of the financial situation and paying ability of the partner is very important aspect during securing of market position of the organization in present time.

\section{Present state of Indebtedness Solving}

Present state of the business is characterized by development of finances, international business and new methods of the organizations management with goal to increase effectiveness and competition of the organizations activity. Permanent changes in the market economy cause necessity to observe financial situation of organizations. Due to the mentioned mainly financial situation is interest of the organizations management. Most rapid and effective method for determination of financial situation is financial analysis with goal to determine what factors and by what intensity caused financial situation and to find out problems of the organization, its weaknesses and strengths, reserves, etc.

For description of financial situation there are used numbers of financial indexes that enable to compare firm with other firms, resp. branch indexes. Their choice depends on the organization goals. Any organization has practically specific goals; some of them are general goals. For example, every organization wants to be successful. Financial indexes are chosen according goal of financial analysis.

Due to the problems with liabilities payment, organization observes many times indexes of paying ability. It can be characterized by rate indexes (liquidity) as well as differential indexes (cash flow). [8]

But existence of industrial organizations has its own specifications, since they are inseparable part of the industrial chains. Demand on their products is many times connected on the volume of the demand on final products.

Liquidity management is very important and sophisticated activity. In case organization does not have proper level of liquidity, it is threatened by bankruptcy. In case organization has surplus of liquidity, it threatens its future effectiveness due to not investing of free money to assets. 
[2]

Observing of paying ability in market economy is most important and mostly followed area not only by management of the firm, but also by external subjects of the organization. For such partners (mostly business partners) there is not decisive if organization has a profit, or how it is using foreign capital. Criteria number one is ability to pay. Goal of any organization should to be providing of permanent ability to pay. Reasons of inability to pay can be high rate of money investing in claims after payable period, in stocks or in not sufficient using of long term property or target orientated money investing in bank accounts. Also financial risks can be other reasons of solvency - currency risk, credit risk, but especially risks due to the inability to pay from the side of debtor.

In some post communist countries there is opinion that there are existing branches with good financial health and branches that have ill financial situation. For example there is an opinion that firms from the not energetic sector are rich and also healthful as for the financial situation.

Economical crisis caused serious problems, connected with ability to pay in many organizations. In present time solvency of the firms in conditions of post communist countries creates wave of further bankruptcy. There is growing rate of the organizations that have problems, causing growing number of bankruptcy of the organizations. Situation in area of solvency is rapidly changing. Organization that have solvency in present time, can be very quickly entering to problems with disability to pay. Worst situation is in the organizations that have problems with long term liquidity, since they have difficulties to provide long term, as well as short term liquidity. [1]

Due to the mentioned we can state that in present time there is still growing importance to follow up ability to pay in any organization, since it has influence also to other organizations, as well as to the whole economical situation. Determination of financial situation demands regarding also different economical conditions in comparison with stable economies. Running financial crisis in the world deepens financial problems of organizations. Monitoring of the financial situation shows that ability to pay is most commonly problem, with which organizations fight. Solvency is one of the basic conditions for the organization existence in the given market conditions.

Ability to pay in the organization is followed up through annual reports, accounting statements and internal information, as well as statistic data about average values of the financial indexes from the individual branches of the industry. [1]

Main reasons for disability to pay are following reasons:

\section{Sales decrease}

Secondary disability to pay

Shortages of credits

High taxes and payments

Total business environment is improving very slowly. Problems that had not been solved can be listed to the following areas:

Still high liability to pay of business area (in comparing with other members states in EU, payments cause burden of economy).

Rights reclaiming did not improve. Long claims reclamation by judiciary way cause problems with secondary disability to pay and accounting problems.

Indebtedness among firm is growing, payable periods for provided goods and services are lengthening, and paying discipline is decreasing.

Law about estate duty (administration is at the side of communities) enables to increase such duty due to the performance of business activity finally 20-25 times. By this way duty operates as punishment for the business not as a motivation factor for development, it is rather obstacle for the development, modernization and renovation of the property.

Difficult access to the long term financing. According national agency for SMEs development $65 \%$ of SMEs assume necessary to improve credits availability in EU only $15 \%$ SMEs consider finances availability as an obstacle.

Total volume of credits is problem in case when businessman realizes every condition for application of credit, but do not obtain credit since bank is not able or not willing to borrow the Money. Volume of credit reaches in some post communist countries $26 \%$ rate on GDP, but in $\mathrm{EU}$ it is $85 \%$.

Great problem is also guarantee for credit that transcends their possibilities in spite of the reform of right of lien. [4]

Banks demand bank acceptance for credit insurance, since juridical reclamation during „normal"guarantee is too long.

Juridical process for solving of business conflict and organization liquidation is too long as well. Solving of business conflicts takes approximately double time of OECD average (420 against 233 days).

From 1st May, 2004 there are directions of EU, applied in SMEs, which demand observance of relevant prescriptions and measurements in every sectors and their observance leads to the finishing of the activity and lately also liquidation of the company.

In post communist countries there was time advance of support payment and transiting from advance allocation to proving after expiration of a year, and therefore organizations started to have problems with running financing. Organizations were not financially prepared for the new system of support providing. They did not have created sufficient financial reserves for bypassing due to the revenue situation from the previous years.

\section{Methodology}

Indexes of indebtedness serve for observing of the financial structure development that means searching of own and foreign capital using. Financial stability of the firm is in- 
fluenced significantly mainly by the rate of own and foreign sources. In case firm disposes with sufficient high rate of own sources, firm is stable, independent as for its further development. In case firm disposes only with low rate of own sources and high rate of foreign sources, firm can have problems during supplementary capital obtaining, during further development and it is also very negative signal for the firm's business partners. [6]

Generally we can say that own capital is more expensive then foreign capital since dividend must bring higher profit then in case of money investing to the bank. Many times it depends with risk of the capital, respectively risk of the investment. Mainly this factor causes that organizations dispose with foreign capital except of own capital. [11]

There is connection among organization indebtedness and its liquidity that can be expressed the best by following argument: „What you are borrowing today, you will need to return in the future. " That means foreign capital payment causes liquidity decreasing (mainly immediate liquidity) due to the influence of financial sources decreasing. [13]

One of the ways for solving of problems with liquidity and indebtedness is to deal with financial investment. Financial investment is not directly connected with the concrete subject or business activity, since it has character of financial transaction among participated subjects. Such financial transaction is documented at the security paper with defining of conditions how subject A provides money for subject B. Advantage of financial investment results from the owing and business with securities that bring higher profit and revenues than common interest rates from bank deposits. [10]

Due to the riskiness of the financial investment there is possibility to decrease risk through portfolio of securities. Main aim of portfolio forming is diversification - allocation of investments to the various securities with goal to decrease risk, connected with the individual securities. Value of the portfolio is given by volume of contributions for owner. [9]

Basic rules for construction of proper portfolio are as follows:

negatively correlated revenues

independent movement of revenues

effective portfolio - any portfolio with lowest risk and comparable expected revenue

growing of assets number in portfolio means decreasing of portfolio dispersion and moving to the average assets covariance [12]

investors want to have without regard to their preferences only certain combination of concrete assets - riskless assets and market risky portfolio.

\section{Results}

Financial situation of the analyzed mining organization is negative due to the great measure of indebtedness. [15] There is therefore necessity to increase own capital in the organization. Resulting from the mentioned possibility to solve such negative situation through financial investment we try to construct proper portfolio of securities that could bring demanded revenues (with assumption of correspondent risk regarding) that could help the organization to pay foreign sources and provide its ability to pay. [7]

Suggestion of securities portfolio consisted from 5 organizations and 2 investment funds (IF) with increasing value of shares. Organizations are mutually negatively correlated that means they are organizations from various branches and such correlation can decrease portfolio risk. Values of the companies' shares are used from the results of periodic auctions. Results are illustrated in the following table 1 .

Table 1. Results of period auctions

\begin{tabular}{llll}
\hline Organization & $\begin{array}{l}\text { 3rd } \\
\text { auction }\end{array}$ & Revenue $-\mathbf{r}$ & $\begin{array}{l}\text { 14th } \\
\text { auction }\end{array}$ \\
\hline 1 & 640 & 1,66 & 1700 \\
2 & 381 & 2,04 & 1157 \\
3 & 1000 & 1,74 & 2744 \\
4 & 940 & 0,27 & 1190 \\
5 & 1534 & 1,49 & 3818 \\
6 & 76 & 4,13 & 390 \\
7 & 444 & 2,38 & 1500 \\
\hline
\end{tabular}

Revenue of the investment - measure of revenue or measure of investment profitability is defined by following equation:

$$
\mathrm{r}=\left(\mathrm{I}_{1}-\mathrm{I}_{0}\right) / \mathrm{I}_{0}
$$

where: $r$ - revenue of the investment

$\mathrm{I}_{1}$ - final value of the investment

$\mathrm{I}_{0}$ - initial value of the investment [14]

Defined profitability is calculated for period that is equal to the durability of the investment. But in the practice measure of profitability is calculated during basic period one year. [3]

During calculation of portfolio profitability we resulted from the profitability of the individual securities in the portfolio as well as from the rate of capital invested to the securities on the total volume of capital, invested to the portfolio of securities. In case of 5 shares purchasing from every suggested organization total invested sum will be 62 $495 €$. Profitability of the suggested portfolio is $\mathrm{R}=1,6886$ $=170 \%$.

Revenue from the portfolio of securities equals

$$
\mathrm{R}=62,495 \times 170 \%=106,241.5 €
$$

Investment risk can be measured according following indexes:

dispersion

standard deviation

$$
\operatorname{var}=\delta^{2}(R)=\sum_{i=1}^{n} p_{i} x\left(r_{i}-R\right)^{2}
$$


where:

var, $\delta^{2}-$ dispersion

$p_{i}$ - probability of $i$ asset revenue, lio

$\mathrm{p}_{\mathrm{i}}=$ capital invested to securities / total capital of portfo-

$\mathrm{ri}-\mathrm{i}$ revenue of the asset

$\mathrm{R}$ - expected revenue of the asset (middle value of the revenue)

$\mathrm{R}=\sum \mathrm{p}_{\mathrm{i}} \times \mathrm{R}_{\mathrm{i}}$

$\delta=\sqrt{ }$ var, standard deviation

In case of suggested portfolio dispersion and standard deviation is calculated as follows:

$$
\delta=\sqrt{0,45802}=0,67675
$$

Table 2. present results from the whole calculation.

\begin{tabular}{|c|c|c|c|c|c|}
\hline $\mathbf{r}_{\mathbf{i}}$ & $\mathbf{p}_{\mathbf{i}}$ & $\mathbf{p}_{\mathbf{i}} \mathbf{x} \mathbf{r}_{\mathbf{i}}$ & $\mathbf{r}_{\mathbf{i}}-\mathbf{R}$ & $\left(r_{i}-R\right)^{2}$ & $p_{i} \times\left(r_{i}-R\right)^{2}$ \\
\hline 1,66 & 0,136 & 0,22576 & $-0,0286$ & 0,00081796 & 0,0001124256 \\
\hline 2,04 & 0,092 & 0,18768 & 0,3514 & 0,12348196 & 0,01136034 \\
\hline 1,74 & 0,219 & 0,38106 & 0,0514 & 0,00264196 & 0,00057858924 \\
\hline 0,27 & 0,095 & 0,02565 & $-1,4186$ & 2,01242596 & 0,191180466 \\
\hline 1,49 & 0,305 & 0,45445 & $-0,1986$ & 0,03944196 & 0,012029797 \\
\hline 4,13 & 0,031 & 0,12803 & 2,4414 & 5,96043396 & 0,184773452 \\
\hline 2,38 & 0,120 & 0,2856 & 0,6914 & 0,47803396 & 0,057364075 \\
\hline \multicolumn{6}{|c|}{ SUM - average: } \\
\hline 1,95 & 0,998 & 1,6886 & - & - & 0,458023338 \\
\hline \multicolumn{6}{|c|}{ Results: } \\
\hline $\begin{array}{l}\mathrm{R}= \\
\delta=0,\end{array}$ & $\begin{array}{c}1,6886 \\
7675\end{array}$ & \multicolumn{3}{|c|}{ var $=0,45802$} & $\delta^{2}=0,45802$ \\
\hline
\end{tabular}

\section{Discussion}

Investor regularly does not know clearly consequences, connected with considered projects, since such consequences can be described only probably that means any possible result is associated with certain estimation of its occurrence probability. Such problem creates risky projects that means investor expects at the given situation concrete result, but he must know that real contribution can be different from the expected one. Deviation among expected and real revenue presents risk of the investing.

Therefore success of the investor depends on the understanding and evaluation of the relation among risk and revenue. Successful investing assumes that investor, demanding high expected profits, must be willing to bear also high risk. It means long term solving of the economical problems has to deal not only with solving of profit gaining, increasing of economic efficiency, but also economic security. [5]

The higher is possibility to achieve revenue that is far from the middle value, the higher risk of the considered investment. The higher is standard deviation or dispersion, the higher is possibility to achieve result, different from the middle value.

In case of our considered investments, revenues from investment to organization No 4,6,7 are significantly different from the middle value - from the expected portfolio revenue and therefore these investments are more risky then others.

Standard deviation is probably most useful from the mentioned risk indexes, since its values have the same dimension as revenue. In considered portfolio standard deviation is 0,67 that means there is possibility to achieve result to $67 \%$ different from expected value $-170 \%$ probability. It can be evaluated as significantly high risk.

\section{Conclusion}

Goal of this contribution had been proving that financial investment can help organizations to overcome existing financial problems and strengthening of their financial health. Organizations must solve mainly problems with their liquidity and indebtedness, since such problems can cause spiral of problems and aggregation of financial problems can lead to the bankruptcy of the company as well as its business partners. In the paper we tried to find how suggested investment to the securities could decrease firm's indebtedness. Mainly we constructed portfolio of securities, consisted from 7 different companies' shares with values, used from $3^{\text {rd }}$ and $14^{\text {th }}$ periodic auctions. Results speak about decreasing of indebtedness by the way of created portfolio revenue. These findings correspond with statements of Brealey et.al (2000). Similar construction of securities portfolio could use financial managers for improving of any area of financial situation and financial health of the firms. But there is still necessity to identify strong and weak parts of the organization since financial situation observance plays significant role during constructing of the business aims, new business goals, as well as during strategic development to the future.

\section{References}

[1] I. Bondarevova, „Platobná schopnost' obchodného partnera - riskovat' či neriskovat." Finančný manažment a controlling v praxi, vol. 10, 2010, Bratislava, Iura Edition.

[2] R. Godalan, O. Kadan, M. Pevzner, „Asset liquidity and stock liquidity." Journal of financial and quantitative analysis. 2012, Cambridge, vol 47, issue 2, pp. 333-364.

[3] J. Cheng, M. A. Weiss, "The role of RBC, Hurricane exposure, bond portfolio duration and macroeconomic and industry wide factors in property liability insolvency prediction." Journal of Risk and Insurance, Georges Dionne, HEC Montreal, 2012, vol 79, Issue 3, pp. 723-750.

[4] H. D. Kaya, "The effect of firms characteristics on choice of debt financing." International Journal of Management, Allan Macpherson and Oswald Jones, British academy of management, 2011, vol 28, issue 4, pp. 199-208.

[5] A. Kelišek, J. Klučka, M. Ondrušek, S. Strelcová, „Economic security - a principal component of multilevel security concept in global economy." Communications, vol. 2, Žilina, 2011, pp. 44/48. 
[6] R. Kotulič, P. Király, M.Rajčianová, „Finančná analýza podniku.“ Bratislava, Iura Edition, 2007, 206.

[7] B. Lester, A. Postlewait, R. Wright, "Information, liquidity, asset prices and monetary policy." Review of Economic Studies, Oxford, 2012, vol 79, issue 3, pp. 1209-1238

[8] L. Xiaowia, S. Ronnie, "Liquidity level or liquidity risk? Evidence form the financial crisis." Financial analysts journal. CFA Institute, 2011, vol 67, issue 3, pp. 51-62.

[9] A. Nashikkar, M. G. Subrahmanyam, S. Mahanti, "Liquidity and arbitrage in the market for credit risk." Journal of financial and quantitative analysis, 2011, Cambridge, vol 46, issue 3 , pp. 627-656.

[10] R. Neag, I. Pascan, "From the assumption of continuing the activity to insolvency - debates and reflections." Juridical Current, Petru Maior University of Tirgu Mures, Romania, 2011, vol. 14, Issue 4, pp. 229-236.
[11] C. Osler, G. Hong, "Rapidly increasing corporate debt: Are Firms now vulnerable to an economic slowdown?" Current Issues in Economics and Finance, USA, June 2000, vol. 6, Issue 7, pp.1-6.

[12] R. S. Jaff, D. Barrack, D. Charme, R. Phelan, J. Bailey, "International secured transactions and insolvency." International Lawyer, 2012, vol 46, Issue 1, pp. 253-263.

[13] D. Ziegler, "Capital markets are good for you." Economist, London, 2003, vol. 366, Issue 8310, pp. 14-16.

[14] R.A. Brealey, S.C.Myers, A.J.Marcus, "Fundamentals of cor porate finance." Irwin McGraw Hill, 2000.

[15] M.Cehlár, K.Teplická, A.Seňová, "Risk management as instrument for financing projects in mining industry." SGEM 2011: $11^{\text {th }}$ International Multidisciplinary Scientific Conference, Bulgaria, Albena, 2011, vol.1, pp. 913-920. 